\title{
CONSTITUTIONAL RESISTANCE AS AN ESSENTIAL ABILITY OF MODERN DEMOCRACY
}

\author{
Bogdan V. Lesiv \\ Lomonosov Moscow State University, Moscow, Russian Federation
}

\begin{abstract}
Introduction: every organism has not only its own constitution, but also an attribute of resistance which protects it from external harmful impact. The same way every democratic State must have not only a formal Constitution and legitimate government, but it is not less important to be able to exercise constitutional resistance. There are many fields of constitutional matter which are studied sufficiently, such as status of constitutional legalism (constitutional legality) or separation of powers, but this paper's aim is to disclose the other detached part of democratic mechanism, which can answer the question: why recently existed States with "constitutional legalism" and "separation of powers" were crashed. Theoretical basis of constitutional resistance is disclosed through the doctrines of rule of law and constitutional review and through the works of great founders of western constitutionalism such as Madison, de Tocqueville, Dicey, Sieyes, Sartori and others. The author's original view is based on the practice of different high courts. Experience of constitutional crisis in the one States and successful constitutional resistance in the others demonstrates the practical value of this institution for democratic society. Results: such reflections give an opportunity to propose the formula of constitutional resistance. Allusions to the organic theory of the State bring to the relevant conclusion that constitutional resistance is the Health of the State.
\end{abstract}

Key words: constitutional legalism, independent court, arbitrary power, unconstitutional actions, constitutional review, political discretion, limited power, rule of law, self-restraint.

Citation. Lesiv B.V. Constitutional Resistance as an Essential Ability of Modern Democracy. Legal Concept, 2018, vol. 17, no. 4, pp. 78-84. DOI: https://doi.org/10.15688/lc.jvolsu.2018.4.11

УДК 340.131 .6

Дата получения статьи: 05.09.2018

ББК 67.400 .2 Дата принятия статьи: 22.10.2018

\section{КОНСТИТУЦИОННАЯ РЕЗИСТЕНТНОСТЬ КАК НЕОБХОДИМОЕ СВОЙСТВО СОВРЕМЕННОЙ ДЕМОКРАТИИ}

\author{
Богдан Васильевич Лесив \\ Московский государственный университет им. М.В. Ломоносова, г. Москва, Российская Федерация
}

\begin{abstract}
Аннотация. Каждый организм имеет не только свою собственную конституцию, но и свойство резистентности, которое защищает его от внешнего негативного воздействия. Точно так же каждое демократическое государство должно иметь не только формальную Конституцию и легитимное правительство - не менее важно для него быть способным осуществлять конституционное сопротивление. Существует множество областей конституционной материи, которые достаточно изучены, такие как режим конституционной законности или разделение властей, но настоящая статья раскрывает иную, самостоятельную часть демократического механизма, которая способна ответить на вопрос: почему недавно существовавшие государства с конституционной законностью и разделением властей потерпели крушение? Теоретическая основа конституционной резистентности раскрывается посредством доктрин верховенства права и конституционного надзора, а также через призму работ великих основателей западного конституционализма, таких как Дж. Мэдисон, А. де Токвилль, А. Дайси, Э.-Ж. Сийес, Дж. Сартори и другие. Автор подкрепляет свой оригинальный взгляд на предмет исследования практикой различных высоких судов. Опыт конституционного кризиса в одних государствах и успешной конституционной резистентности в других показывает практическую ценность этого института для демократического общества. Размышления автора предоставляют возможность предло-
\end{abstract}


жить формулу конституционной резистентности. Отсылки к органической теории государства приводят к актуальному выводу о том, что конституционная резистентность - это здоровье государства.

Ключевые слова: конституционная законность, независимый суд, произвол, неконституционные действия, конституционный контроль, политическая дискреция, ограничение власти, верховенство права, самоограничение.

Цитирование. Лесив Б. В. Конституционная резистентность как необходимая способность современной демократии // Legal Concept = Правовая парадигма. - 2018. - T. 17, № 4. - C. 78-84. - DOI: https://doi.org/ 10.15688/lc.jvolsu.2018.4.11

\section{Introduction}

Constitutional legalism is a normal status (condition) of any legal system regarded as modern constitutional democracy with the rule of law and supremacy of the human rights. It's important to point that with respect of the Civil law systems it is preferable to distinguish 'constitutional legalism' from 'legalism' since there are written Constitutions which have independent from the ordinary laws content. So in the Civil law systems we can compare 'legalism' and 'constitutional legalism' as well as we can compare the 'core' rule of law and the extended (liberal) rule of law ('the principle of legality') ${ }^{1}$ in tailored to English law. For instance, in Russia it became possible because of the strict rule of 'normative hierarchy' that arises not only from legal doctrine, but also from the Article 76 of the Constitution of the Russian Federation (supremacy clause) and from some statute provisions (eg section 8 of the Article 213 of the Code of administrative procedure). According to them, the Constitution and Federal Constitutional laws having entrenchments in their adopting process compose a special division of legislation which has supreme legal force towards ordinary statutes of any lawmaking body. Such approach corresponds to Sieyes' theory of constitutional government which is established against tyranny (for restraint of political discretion): "The power exercised by the government has substance only in so far as it is constitutional; it is legal only in so far as it is based on the prescribed [constitutional] laws" [15, p. 12].

At the same time constitutional provisions of those systems are frequently vague with significant legal latitude (including principles of law and human rights), which is named as "general regulation" by professor S. Avakyan [1, p. 69-71, 134], while professor A. Kovler and M. de Salvia called them "guide norms" and "norm-parameters" [8]. Such legal material receives certainty through the
Constitutional Court's interpretation practice having equal legal force to the Constitution itself. It makes possible a situation when an ordinary law is in contradiction with Constitution (sensu lata). Furthermore, it is possible to the public officer to contradict the Constitution by unconstitutional behavior not contradicting particular ordinary law due to the "general regulation" of the first. So 'constitutional legalism' and 'legalism' are the different statuses of Russian and other Civil legal orders. In this regard, a special form of judicial review is justified, which got the name of constitutional review.

To maintain the status of constitutional legalism a State must be resistant to any unconstitutional activity, even it is in conformity with ordinary legalism. Therefore, Dicey characterized constitutional legalism ${ }^{2}$ as "the prevalence of a spirit of [constitutional] legality among the people" [2, p. 175]. It requires a State (the People ideally) to resist unconstitutionality in the name of Sovereign. We propose to name the State's ability to such resist as constitutional resistance.

\section{Mission of constitutional resistance: theory}

The formula of constitutional legalism is impossible without two elements: constitutionality of the laws (statutes) and constitutionality of behavior (actions, omissions). Similar role of constitutional review in upholding of legalism described in respect of the Commonwealth of Australia by S. Gageler, who emphasize a unique role of the Judiciary in determining the constitutionality of government action [4, p. 175]. It reflects a comprehensive value of constitutional control in modern democracy. Not only the legislature is to be a subject of constitutional review, but the executive equally. In other words, constitutional democracy implies that political 
arms must be accountable not only to the People (demos), but also to the Constitution due to the rule of law. Norway Constitution says that even constitutional amendments "must never, however, contradict the principles embodied in this Constitution, but solely relate to modifications of particular provisions which do not alter the spirit of the Constitution" (Article 112). Recalling the realistic theory of Dr. Rudolf von Jhering, the following allusion (mutatis mutandis) may be relevant: cast into the chaotic whirl of political aims, endeavors, interests constitutional justice has forever to feel and seek in order to find the unconstitutionality, and when it has found it, to overthrow the obstacles which would impede constitutional course [6, p. 13-14]. A vivid example of such constitutional resistance is the Privacy of Communication Case (BVerfGE 30, 1/1970) on the merits of "eternal provisions" of German Basic Law [3, p. 92-96].

In Russia the first element of constitutional legalism is ensured by the overriding powers of the Constitutional Court and of the President. They can resist excessive political expediency of the Federal Assembly and Government ('drastic legislation') by declaring certain statutes as not conforming to the Constitution, what entails their legal nullity (lex perfecta). That means statute's constitutionality is presumed, but can be refuted (praesumptio iuris). Despite this, the problem of drastic legislation is often complicated by the subsequent legislator's drastic perception of Constitutional Court's rulings. The relevant sample is a response of Russian Legislature to the require of proportionality contained in Constitutional Court's Judgment № 7-П of April 2, 2002 [10, p. 19].

In the same time, we are forced to state that, according to the current constitutional regulation, the actions (behavior) of the executive officers (even federal ministers) or President are unlikely to be a subject of Constitutional Court's review (lex imperfecta), although such actions are related to the operation of the Constitution (sometimes directly related to the constitutional text). Not every law has a content resulting from the Constitution, and not every provision of the Constitution has exhaustive extension in a law. Therefore, and in respect that the ordinary courts in Russia have limited power to implement and interpret the Constitution, ordinary judicial review (administrative procedure) cannot effectively resist unconstitutional activity of Executive. Thus, the constitutionality of the executive's deeds is presumed, but cannot be contested in constitutional procedure. It is given to self-restraint due (praesumptio iuris et de iure).

J. Madison in Federalist No. 46 stated that in America the executive and judicial powers are absolutely dependent upon the legislative power. It fixes their salaries in general, modifies their organization; and nothing is provided for them to be able to resist its encroachments [11] ${ }^{3}$. That sounds confusing particularly with considering the Madison's reflections on the harm of the tyranny of majority in Federalist No. 10 and later US Supreme Court 'resistance' practice (seems paradoxically, but the first and most influential case is undoubtedly Marbury v. Madison, but the other one). Since Magna Charta was adopted the main purpose of any constitutional act is restriction of arbitrary power and ensuring of limited government what Sartori called 'the telos' of English, American and European constitutionalism [14, p. 855]. In this regard, the Constitution makes us sure that Sieyes's equation "political liberty has its limits, just as civil liberty has" $[15$, p. 6] is respected.

De Tocqueville named justice as a base for limitation of power: "A general law exists that has been made, or at least adopted, not only by the majority of such or such people, but by the majority of all men. This law is justice. So justice forms the limit of the right of each people [to command]" [16, p. 410]. All foregoing describes constitutional resistance as a fight between 'justice', 'spirit of the Constitution', 'general regulation' on the one hand, and 'tyranny', 'excessive political expediency', 'unlimited discretion' on the other hand. If earlier the tyranny was associated with a monarch, now, as a rule, it is coming from the political arms of government which scoop their power from 'will of the nation' (tyranny of majority/ of democracy). But the essence of the tyranny is constantly pernicious for republic no matter its origin.

Exactly because of that judiciary (=justice) is a fear of what de Tocqueville and Madison called 'the tyranny of the majority'. It is justified so far as modern 'democracy' is more than just the will of the majority and must be policed by certain basic rights of equality. ${ }^{4}$ Everybody knows 
Latin phrase "Jus est ars Boni et Aequi" that means that law is exactly the art of equality. European Court of Human Rights also stated that "democracy does not simply mean that the views of the majority must always prevail: a balance must be achieved which ensures the fair and proper treatment of minorities and avoids any abuse of a dominant position" (see Young, James and Webster v. the United Kingdom, 13.08.1981, Series A no. 44, § 63 and Gorzelik and Others v. Poland, 17.02.2004, A no. 44158/98, §90).

According to professor A. Kovler, persistent political practice can create its own 'real constitution' ignoring provisions of the 'formal Constitution' or using its gaps for ungrounded content extension [7, p. 26-29]. But permanent denial of the formal Constitution can lead to its final abolition. Recognizing of a 'real' constitution in contradistinction to the 'formal' one means that Constitution in its original sense is no more real. So far as a 'real' constitution depends on the political decisions, it has neither intention, nor potential to limit the government of the day. In that case the rule of law is replaced by the rule of discretion, and the substitution of values takes place: it is desirable to be governed by rulers rather than by rules ${ }^{5}$. Constitution (from constant) means constitutionality (=certainty, constancy), whereas unconstitutionality means uncertainty, arbitrariness and unpredictability. The formal Constitution gives the society a confidence in the constant rights (legal certainty) and minimal guarantees of welfare no matter who is in power; while the 'real' constitution gives such a confidence only for the last ones. It has no reason to be named the Constitution insofar it doesn't pursue the spirit of constitutionalism. So constitutional resistance means the existence of effective mechanism for withstand such tyranny (usurpation) and excessive political practice imposing personal wishes of rulers on us.

As we can see, only the judicial arm can handle this burden insofar it is impartial and nonpolitical branch which has not political licentiousness, but devotion to the right-based legal tradition. Judges' responsibility is to independently observe for government actions [13, p. 58]. So it is pertinently to mention the other part of Dicey's "legalism" - "the predominance of the judiciary in the constitution" [2, p. 175]. After all we said about the matter of dispute, we must emphasize that, in contrast with the common law systems, the Civil legal orders can effectively exercise constitutional resistance only through the specially established body of constitutional justice (control). Otherwise the generally accepted Kelsen's concept of constitutional review will be belittled.

\section{Mission of constitutional resistance: experience}

As we figured out, theoretical mission of constitutional resistance is to withstand any exercise of arbitrary power (unconstitutionality) for upholding the regime of certainty, justice and constitutional legalism. Consequently, a low level of constitutional resistance entails disability of such withstanding, and constitutional crisis is coming.

Failure of resisting unconstitutional activity in 1991-93 led to the most significant constitutional crisis in the Russian State, which resulted in termination of lawfully established constitutional regime and in arbitrary abolition of the Constitution. Without a political and personal assessment of those events we must note several pure legal points. Firstly, the All-nation referendum of March 17, 1991 as a constitutional measure decided that renewed Soviet Union must be saved with recognizing of human rights (over $76 \%$ supporting), what obligated the government to execute the will of the nation. In the Russian Federation (as a republic of Union) more than $71 \%$ of people supported such decision. The same referendum in the Russian Federation established a post of President, although with over $2 \%$ more votes 'against'. Paradoxically that President Yeltsin agreed with the second decision, he was elected and took his power from the one part of the 1991 referendum, but at the same time he completely ignored the other part of the nation's will. In contradiction to the referendum's order he signed on December 8, 1991 the Agreement of Soviet Union abolition.

Moreover, on March 20, 1993 President Yeltsin declared the Constitution invalid and arbitrary proclaimed a "special regime of government administration". President, whose power is restricted by the Constitution to prevent the tyranny, declares it invalid. Even the king has no such power since Constitution is adopted. Constitutional Court of Russia declared such actions of President unconstitutional by its 
Judgment of March 23, 1993, but this decision had no effect.

By the order of September 21, 1993

President Yeltsin arbitrary dissolved the Parliament and established a "new system of government'. Such actions were declared unconstitutional by the Constitutional Court's Judgment, which entered to a legal force at once. On September 23 President called new Parliament elections without appropriate constitutional authority. By the Parliament decision of September 24 he was impeached due to the Article 121.6 of the Constitution, but he arbitrary continued 'presidential' activity. To suppress constitutional claims of Parliament and Constitutional Court President Yeltsin used the armed forces, shot the Parliament House and suspended the practice of the Constitutional Court.

Those sad events made a vivid example of extremely low level of constitutional resistance. There was no effective mechanism for withstand tyranny (usurpation) and excessive political practice. Therefore, crisis of the Constitution inevitably brought the deep political, social, economic and demographic consequences. The Judgments of protector of the Constitution Constitutional Court, highest court in the State were ignored. Justice, in the person of the Judiciary, could not resist the political encroachments. Different personal estimates of a soviet regime may be justified, but it is undoubtedly that the disability to constitutional resistance demonstrated in those days could entails destruction of any State, even democratic.

It is notably that even now Russian courts have no sole power to punish for disobedience or contempt ${ }^{6}$. According to the 2017 Constitutional Court report, 28 Judgments of this court are not fulfilled by the Executive and the Legislature since 2008, what constitutes a violation of the Article 80 of the Federal constitutional law on Constitutional Court of the Russian Federation ${ }^{7}$.

Another example can be mentioned in respect of Pakistan constitutional crisis in 1997. Supreme Court suspended a constitutional amendment that protected prime minister from any dismissal, but Prime Minister Nawaz Sharif pressed President Leghari, threatening him by impeachment, to appoint a new Chief Justice. Chief Justice Sajjad Ali Shah accused Sharif of undermining the judicial independence. Sharif was chilled out by the armed forces, but even so he received dominance subsequently.

Overall, we should recognize that sad experience of constitutional resistance is not prevailing in western democracy. There are some vivid successful examples. Lithuanian constitutional crisis of 2004 was hardly resisted by Constitutional Court, which has established three gross violations of the Constitution in actions of President Paksas, including a breach of his constitutional oath. Lithuanian Constitutional Court stated that constitutional liability of a president who has grossly violated the Constitution or breached the oath is one of the ways of protecting the State for the common good of society, as provided for in the Constitution ${ }^{8}$. The sample of 'daily' constitutional resistance is the US Supreme Court case of 2014 when actions of President Obama had been declared unconstitutional (violation of the Recess Appointment Clause of the U.S. Const.-) ${ }^{9}$.

It is important to take a note that in both the 'sad' cases the armed forces played a leading part in constitutional crisis. That means only established mechanism is not enough for constitutional resistance. Russia in 1991-93 had the Constitutional Court that actively fought with unconstitutionality within its competence. But its lawful measures were not ensured by any real power, unlike the encroachments of President. Therefore, mechanism of constitutional resistance must be not theoretical and illusory, but practical and real. From this point of view constitutional resistance is an objective ability of the State to withstand unconstitutionality.

\section{Health of the State}

According to Merriam-Webster medical dictionary, resistance is a power or capacity to resist, especially the inherent ability of an organism to resist harmful influences (as disease, toxic agents, or infection) ${ }^{10}$. In its turn 'resistant' means giving, capable of, or exhibiting resistance. We think that foregoing legal discourse is quite enough for successful extrapolation of this medical term on legal matter.

The need of political freedom and the need of possibility to political self-realization are doubtless in democratic society as well as the need of legal certainty. This is true insofar they are the 
guarantee of social progress and the base of effective strategic decisions. But such decisions form political practice, and the last one may be constructive and useful or selfish and destructive for the State. Not only our behavior and prudence (lifestyle) influence our state of health, but in the same way political practice (actions and behavior) of the government of the day constitute a lifestyle of the State, which can lead to cheerfulness as well as to illness. Democratic organism is normally functioning by virtue of relying on certainty (as Hobbes already said in Leviathan about civilization) and on a law-abiding person, or, in other words, by virtue of constitutional legalism. Unconstitutional actions are alien like an infection in such organism; they poison it by disruptive impact on legal certainty; they can paralyze it or, as we have seen on the foregoing examples, they can even be lethal to the State.

For instance, professor of Law M. Kumm identifies four types of pathologies of the political process that occasionally infect democratic decision-making, and that even mature democracies are not generally immune from. Among the others, he marks the vice of thoughtlessness based on tradition, convention or preference, that give rise to all kinds of inertia to address established injustices [9, p. 163]. Here we can recognize one of the earlier discussed exercises of the tyranny of majority. It is important that professor Kumm names proportionality-based judicial review as a right way to contest the acts of public authorities and to demand a public reasons-based justification of political expediency.

$G$. Jellinek in XIX century already wrote that "the letters of the Constitution conceal unknown powers hitherto" [5, p. 25]. By these words he started a long thinking about the doctrine of 'implied powers' according to which a law opens these powers, but only a judge is able to bring them into life. At the same time, the highest art is not to withdraw "implied powers" from the text of the Constitution, but to introduce them into it through constitutional review. Otherwise, the "unknown powers", which like a liquid filling the gaps of the written Constitution, sooner or later will come out of the constitutional shores (they will form the 'real' constitution). Therefore, a task of constitutional resistance is not only to keep this "liquid" in the shores of the Constitution (review of compliance with basic provisions), but also to check for the presence of malignant "infections" (arbitrary and ungrounded powers).

Necessary formula of constitutional resistance should content:

1. Checks and balances, which have a real force as well as a legal force;

2. Predominance of legal liability and of the judiciary (constitutional review);

3. Effective remedies of protection against an arbitrary power that are to be exercised by the independent court (including the test of proportionality);

4. Dual constitutional review (actions of the Executive must be subjected to review as well as the statutes of Legislature);

5. Inability to avoid the review or the consequences (prescribes) of the review; Judgments must be ensured by real force even referring to those in power;

6. Courts must have a sole power to punish for contempt and disobedience, it makes us confident on their independence;

7. Impossibility (not impermissibility, not unlawfulness) to oppose a political power to legal liability since the legal order is accepted by majority of all men as only way of justice; it is grounded on the natural law by sacrificing part of each other's freedom for common welfare ${ }^{11}$.

Immunity is the inherent vital capacity existing for our effective protection from different infections regardless of our color of skin or hair, and no matter what kind of social, sexual or political preferences we endorse. The same way constitutional resistance must be the immunity of the State organism protecting it in spite of any political expediency, in spite of the will of majority or minorities, in spite of chaotic whirl of what Madison called as factious tempers, local prejudices or sinister designs [12]. So long as the organism of man has an ability to resist illness, it has good health; so long as the organism of State has an ability to resist unconstitutionality, it has certainty, stability, progress and welfare which are the Health of the State.

\section{NOTES}

\footnotetext{
${ }^{1}$ See Lord Hoffman in R v Secretary of State for the Home Dept, ex p Simms [1999] (at 131).

2 Mutatis mutandis, in the UK 'legalism' and 'constitutional legalism' are the same, according to
} 


\section{ТЕОРИЯ И ПРАКТИКА ГОСУДАРСТВЕННО-ПРАВОВОГО РАЗВИТИЯ}

Dicey, because of uncodified Constitution and his view on the 'core' rule of law.

${ }^{3}$ See ALRC Report 'About protections from statutory encroachment in Australia’ No. 129, part 15. Judicial Review.

${ }^{4}$ See Lord Hoffmann in R (Alconbury Developments Ltd) v Secretary of State for the Environment, Transport and the Regions [2001] at [70].

5 The correct formula sounds as 'it is desirable to be governed by rules rather than by the discretion of rulers'.

${ }^{6}$ Indictment for contempt or for disobedience (articles 297 and 315 of the Criminal Code of Russia) is exercised by discretion of the executive agency Federal bailiff service.

${ }^{7}$ Analytical Report on the implementation of decisions of the Constitutional Court of the Russian Federation. Official site of the Constitutional Court of Russia. URL: http://www.ksrf.ru/ru/Info/Maintenance/ Informationks/Pages/ReportKS2017.aspx.

${ }^{8}$ ECtHR. Paksas v. Lithuania (GC). Application no. 34932/04. Judgment of January 6, 2011, nos 27, 30.

9 See National Labor Relations Board, Petitioner v. Noel Canning, et al. 573 U.S. (2014).

${ }^{10}$ Merriam-Webster medical dictionary. Official site. URL: https://www.merriam-webster.com/ dictionary/resistance\#medicalDictionary.

11 See Locke J. Second Treatise of Government. Jonathan Bennett, 2017, part 8, p. 32.

\section{REFERENCES}

1. Avakyan S.A. Constitutional Law of Russia. Moscow, NORMA Publ., 2014, vol. 1.

2. Dicey A.V. Introduction to the Study of the Law of the Constitution. London, 1960.

3. Dorsen N., Rosenfeld M., Sajo A., Baer S. Comparative constitutionalism: Cases and materials. West Publishing company, 2003.

4. Gageler S. Foundations of Australian Federalism and the Role of Judicial Review. Federal Law Review, 1987, vol. 17, iss. 3, pp. 162-198.
5. Jellinek G. Constitutions, their amendments and transformations. Saint Petersburg, Law Publ., 1907. (in Russian).

6. Jhering R. The struggle for law. Chicago, Callaghan and Co., 1915.

7. Kovler A. Constitution "Formal" and "Real". Polis. Political Studies, 1998, iss. 6, pp. 26-31.

8. Kovler A. Judicial activism: separate opinions of Judges of the European Court of Human Rights. Russian yearbook of the European convention on human rights. Moscow, Statute, 2016, iss. 2.

9. Kumm M. The Idea of Socratic Contestation and the Right to Justification: The Point of RightsBased Proportionality Review. Law \& Ethics of Human Rights, 2010, vol. 4, iss. 2, art. 1, pp. 141-175.

10. Lesiv B.V. Vox Populi of Local SelfGovernment in Russia: Issues of the Liability of Municipal Bodies to the People (on the Example of the Practice of thePrimorsky and Khabarovsk Territories). Electoral Legislation and Practice, 2018, no. 3, pp. 17-23.

11. Madison J. The Influence of the State and Federal Governments Compared. The Federalist Papers, 1788, no. 46 (January 29).

12. Madison J. The Same Subject Continued: The Union as a Safeguard Against Domestic Faction and Insurrection. The Federalist Papers, 1787, no. 10 (November 23).

13. Mahoney P. Judicial Activism and Judicial Self-restraint in the European Court of Human Rights: Two Sides of Same Coin. 11 Hum. Rts. L.J., 1990, vol. II, no. $1-2$, pp. $57-88$.

14. Sartori G. Constitutionalism: a preliminary discussion. American Political Science Review, 1962, vol. 56, no. 4, pp. 853-864.

15. Sieyes E.J. What is the Third Estate? University of Oregon website. URL. https://pages.uoregon.edu /dluebke/301ModernEurope/Sieyes3dEstate.pdf.

16. Tocqueville A. Democracy in America (a bilingual French-English ed.). Indianapolis, Liberty Fund Inc., 2010, vol. 2.

\section{Information about the Author}

Bogdan V. Lesiv, LL.B, MRes (Law), Department of Constitutional and Municipal Law, Lomonosov Moscow State University, Leninskie gory St., 1, blds. 13-14, 119234 Moscow, Russian Federation, forbod@bk.ru, https://orcid.org/0000-0001-8085-3983

\section{Информация об авторе}

Богдан Васильевич Лесив, магистрант кафедры конституционного и муниципального права, Московский государственный университет им. М.В. Ломоносова, ул. Ленинские горы, 1, корп. 13-14, 119234 г. Москва, Российская Федерация, forbod@bk.ru, https://orcid.org/0000-0001-8085-3983 